This article was downloaded by: [Fondren Library, Rice University ]

On: 12 September 2013, At: 11:24

Publisher: Routledge

Informa Ltd Registered in England and Wales Registered Number: 1072954 Registered office: Mortimer House, 37-41 Mortimer Street, London W1T 3J H, UK

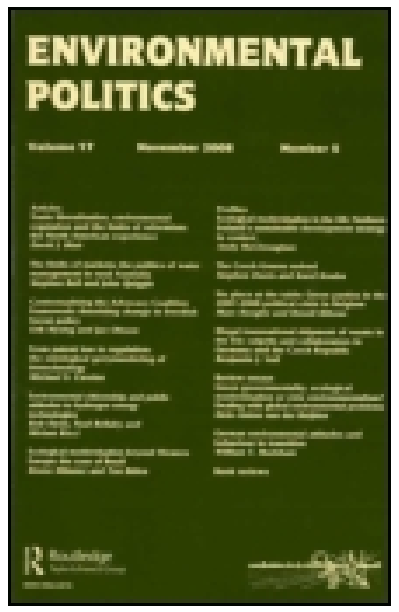

\title{
Environmental Politics
}

Publication details, including instructions for authors and subscription information:

http:// www. tandfonline.com/loi/ fenp20

\section{From politics to prophecy: environmental quiescence and the 'peak-oil' movement}

\author{
Matthew Schneider-Mayerson ${ }^{a}$ \\ a Department of American Studies, University of \\ Minnesota, Minneapolis, Minnesota, USA \\ Published online: 11 Sep 2013.
}

To cite this article: Matthew Schneider-Mayerson (2013) From politics to prophecy: environmental quiescence and the 'peak-oil' movement, Environmental Politics, 22:5, 866-882, DOI: $10.1080 / 09644016.2013 .818303$

To link to this article: http:// dx. doi.org/ 10.1080/09644016.2013.818303

\section{PLEASE SCROLL DOWN FOR ARTICLE}

Taylor \& Francis makes every effort to ensure the accuracy of all the information (the "Content") contained in the publications on our platform. However, Taylor \& Francis, our agents, and our licensors make no representations or warranties whatsoever as to the accuracy, completeness, or suitability for any purpose of the Content. Any opinions and views expressed in this publication are the opinions and views of the authors, and are not the views of or endorsed by Taylor \& Francis. The accuracy of the Content should not be relied upon and should be independently verified with primary sources of information. Taylor and Francis shall not be liable for any losses, actions, claims, proceedings, demands, costs, expenses, damages, and other liabilities whatsoever or howsoever caused arising directly or indirectly in connection with, in relation to or arising out of the use of the Content.

This article may be used for research, teaching, and private study purposes. Any substantial or systematic reproduction, redistribution, reselling, loan, sublicensing, systematic supply, or distribution in any form to anyone is expressly 
forbidden. Terms \& Conditions of access and use can be found at http:// www.tandfonline.com/page/terms-and-conditions 


\title{
From politics to prophecy: environmental quiescence and the 'peak-oil' movement
}

\author{
Matthew Schneider-Mayerson* \\ Department of American Studies, University of Minnesota, Minneapolis, Minnesota, USA
}

\begin{abstract}
Adherents of the 'peak-oil' theory believe that resource depletion will cause an imminent social collapse that will lead to a simpler and more environmentally balanced world. Although American 'peakists' are extremely concerned with environmental issues, their awareness of the scale of ecological crises (such as climate change), gloomy evaluation of the state of American environmental politics, and vision of a post-apocalyptic future lead them to retreat from politics. Their beliefs, inaction, and impact on American environmental politics are explored.
\end{abstract}

Keywords: peak oil; inaction; American left; resource depletion; environmentalism; fatalism; Transition Towns

\section{Introduction}

The causes of American inaction in the face of pressing ecological crises such as climate change have been the subject of a great deal of theorising. Scholars have rightly pointed to a number of factors, including conservatives' denial of science (Jacques et al. 2008), the rise of neoliberalism (Niessen 2010), and the unique psychological dimensions of some environmental issues (Nickerson 2003). Others have looked to the environmental left itself. Following Nordhaus and Schellenberger's (2004) essay on 'The Death of Environmentalism', scholars seemed to have reached a funereal consensus on the state of American environmentalism - in Environmental Politics' 2008 special issue on 'Environmentalism in the United States', for example, every article used the word 'failure' (e.g. Bryner 2008). In explaining this failure, the passivity and political inaction of the American left has received insufficient attention. Here, I examine the ideology and political quiescence of a subculture of American leftists who are deeply concerned about environmental issues but have turned away from political solutions: the 'peak-oil' movement.

For these Americans, alienation from mainstream American politics and the frustration of environmental initiatives pushed environmental concerns from the

\footnotetext{
*Email: schne641@umn.edu
} 
realm of politics to prophecy. While Environmental Politics and other journals have devoted increasing attention to the threat of 'peak oil' (e.g. Gonzalez 2007, Bardia 2009, Curtis 2009, Mulligan 2010, 2011), scholars have largely ignored the subculture of actual peak-oil believers. Here, I break new ground by looking beyond the disembodied 'discourse' of peak oil 'eco-apocalypticism' (Szeman 2007, p. 817) to examine flesh-and-blood 'peakists' - Americans for whom beliefs about oil depletion and other ecological crises are so central to their sense of self that they constitute an 'ecological identity' (Thomashow 1995). We might expect peak-oil adherents to be deeply involved in environmental politics, but as a result of their political marginalisation and belief in the futility of political action, most retreat to personal preparations for the expected environmental and societal collapse.

At an historical moment when solutions to ecological crises through electoral politics seem especially unlikely to many Americans, the prophecy of peak oil provides one means of imagining a significantly different world. Peakists see 'peak oil' - the point in time when the maximum rate of petroleum extraction is reached - as an imminent, transformative event that will put an end to American imperialism and capitalism and deliver a superior, more environmentally balanced post-apocalyptic future. This revolution will not be authored by elected politicians or social movements, but by the petroleum-dependent 'American way of life' tripping over its ecological limits. I argue that the peak-oil movement represents a new configuration of American radical environmentalism, and suggest that certain aspects of this group's political quiescence reflect a similar dynamic among the broader environmentally aware U.S. left. Without including the peak-oil movement and its ideology, our understanding of environmental politics in the twenty-first century United States remains incomplete.

\section{The peak-oil movement}

To most scholars, 'peak oil' serves as shorthand for energy depletion, but for a subculture of Americans in the early twenty-first century, it became an ideology. Between 2004 and 2011, more than 100,000 Americans came to believe that oil scarcity would lead to the imminent collapse of industrial society and the demise of the United States. ${ }^{1}$ Many changed occupations, purchased land, and even left their partners as a result of their newfound belief. For adherents, 'peak oil' is an ideology, an entire system of beliefs. ${ }^{2}$ It refers to a dramatic teleology in which energy scarcity leads to the collapse of the late-modern capitalist system. Believers describe their awareness of this impending event in terms strikingly similar to a religious conversion. Most recall the exact moment they 'learned about peak oil', their emotional reaction, dramatic change in thinking, and reordering of their personal cosmologies. A retired meteorologist noted that 'peak oil can consume you. It changed my perspective on everything'. A South Carolinian in his early fifties confessed that 'all of life is now seen through the lens of a lower energy future and that has affected all of my choices'. 
Another believer said that his 'future plans are framed by a peak-oil future'. Many use the metaphor of awakening to describe the change: 'once I grasped the gravity of the situation it was like waking from a dream to find the world is not all as it seems'.3

The potentially wide-reaching implications of oil depletion have been the subject of dozens of recent scholarly articles in a wide range of fields and disciplines, from tourism studies (Becken 2008) to epidemiology (Hanlon and McCartney 2008). However, the peak-oil movement has been overlooked because of its virtual organisation. While the Internet enables the rapid creation of subcultures, it can also obscure the extent to which these groupings are reflected in real-world action and psychological or emotional investment (Wilson 2006). Peakoil believers generally meet on the Internet, 'prep' for the post-oil future alone, and rarely seek publicity. To access this largely hidden population, my research combined multiple methodologies: two large-scale online surveys of participants ( $N=1128$ and $N=628$ ); analysis of websites and online forums; literary analysis of peak-oil fiction; ethnographic research conducted at 'Transition Towns' and peak-oil conferences; and interviews with movement leaders. ${ }^{4}$

\section{American peakists}

Although believers can be found around the world - the Association for the Study of Peak Oil has chapters in 23 countries - the phenomenon is focused in the United States (70-77\%), where believers have proven especially passionate and dedicated. Here, I am primarily concerned with American adherents, who are wealthier and better educated than most Americans. ${ }^{5}$ Peakists are primarily white (89-91\% of survey respondents), male (73-84\%), middle-aged (average age of 47 ), and upper middle-class (average yearly income between $\$ 75,000$ and $\$ 100,000)$.

Peakists are deeply pessimistic about the potential of other fossil fuels and nonrenewable energy sources to replace petroleum, not only as fuel for transportation but to produce plastics, pharmaceuticals, and the vast array of petrochemicals. They hold practical objections to each option - coal, nuclear, solar, wind - that constitute articles of faith (e.g. Heinberg 2003, Kunstler 2005). Even if an Apollo-calibre project of renewable energy development were to be implemented immediately, they say, it would be too little, too late. As billions of people in industrialising nations seek and achieve a first-world, high-energy lifestyle, global demand for a finite resource will only grow; 'resource wars' (Klare 2001) over remaining petroleum will preclude any transition to alternative energy sources. American believers were much more likely to see 'resource wars' and an 'apocalyptic scenario' (including a worldwide 'die-off' of billions of people and a global economic collapse) as probable future events than their Canadian or European counterparts. ${ }^{6}$

Despite its name, the peak-oil ideology is more accurately described as 'peak everything' (Heinberg 2007), reflecting the limits-to-growth environmental 
paradigm that emerged in the United States in the late 1960s but fell out of favour in the 1980s. Peakists are concerned with the threat of an ecological collapse of which petroleum is the central symbol, and most consider peak oil and climate change to be interconnected 'twin crises'. A young man from Nevada observed that oil depletion is not an isolated issue but 'part of a larger pattern including climate change, over-population, degradation of our physical earth (deforestation, denuding of farming landscapes, etc.)'. A Virginia woman in her late forties agreed, claiming that peak oil is 'part of larger environmental crisis. Other resources are peaking or declining as well (fertile topsoil, wild fish, pollution sinks)'. A New York City man identified the problem even more broadly: 'how humans interact with the environment overall'.

The size of a decentralised movement with survivalist tendencies is impossible to definitively determine, but the significant number of Americans who subscribed to peakism is borne out by the visitors to and members of subculture websites. In September 2008 alone, James Howard Kunstler's 'Clusterfuck Nation' had 190,000 unique visitors and 97,000 return visitors from the United States alone. ${ }^{7}$ By December 2009, the website 'Peak Oil News and Message Boards' had more than 19,000 American members. ${ }^{8}$ Research on 'lurkers', who visit membership sites but do not join or post, estimates that members comprise only $10 \%$ of visitors (Nonnecke and Preece 2000), which suggests that almost 200,000 Americans were regularly visiting just one of many peak-oil websites at that time.

Although peakists stress the need for collective solutions to ecological issues such as oil depletion and climate change, most prepare for the post-oil future alone or with their immediate families. My surveys showed that after becoming 'peak-oil aware', almost three-quarters began stockpiling food, more than a third purchased a more energy-efficient car, one out of four moved to a smaller or more energy-efficient home, and one out of five changed occupation. ${ }^{9}$ They also created a rich, sprawling virtual community of websites, blogs, Podcasts, YouTube channels, poems, cartoons, video games, online forums, and even peak-oil therapy and couples counselling. ${ }^{10}$

The 'Transition Town' initiative - a franchise model of intentional communities whose participants attempt to build resilient, sustainable communities in preparation for peak oil and climate change - is widely hailed as an ideal response to these threats, and has received a great deal of scholarly attention (e.g. Bailey et al. 2010, North 2010, Scott-Cato and Hillier 2010, Smith 2011). However, most scholars have focused on British Transition Towns, and few have examined its low participation rate in the context of the broader peak-oil community. Only one out of four respondents to my surveys had participated in any such collective or political responses, and many of these had attended one meeting and never returned. Instead, most said that their chief priority was 'protecting themselves and their family from the immediate consequences of peak oil', instead of 'educating others' or 'working with others to try to avert the worst consequences'. 


\section{Peak oil and the American left}

This individualism is significant because peakists might otherwise be expected to spearhead the demand for an overhaul of American environmental policy. Most have made significant life changes as a result of their ecological beliefs, and they are strong believers in anthropogenic climate change $-81 \%$ reported being 'worried' about it (Howard 2009, p. 5), compared to 60\% of Americans generally (Newport 2012). ${ }^{11}$ The peak-oil movement has been characterised by journalists as the 'liberal apocalypse' (Urstadt 2006) for good reason: 56\% of American peakists described themselves as 'liberal' or 'very liberal', compared to only $21 \%$ of all Americans (Saad 2010b). Given the opportunity to choose from a wider selection of political categories, approximately $8 \%$ call themselves 'anarchist', 11\% 'socialist', 20\% 'progressive', 15\% 'liberal', and only 5\% 'conservative'. Beyond labels, their values put them far to the left of most Americans. A total of $81 \%$ think that gay men and women should be able to legally marry (with $10 \%$ having no opinion), for example, and $80 \%$ agreed that 'we don't give everyone an equal chance in this country'. ${ }^{12}$

In surveys and interviews and on the web, many advance a leftist critique of the United States as an imperialist power and even of capitalism itself. They view mainstream American platitudes as a mix of misinformation and outright falsehoods. For them - judging from comments on forums - 'the American Dream is just propaganda used to justify selfish materialism' ('The American Dream?') and "the sad reality of the matter is that "the American Dream" is dying. Every month more American families are slipping out of the middle class and into poverty' ('Peakoil.com 2011a'). One poster scoffed, in a thread on the subject of 'American exceptionalism', 'we have been the best colonialists in the world. We sucked the world dry taking a full quarter of its resources for ourselves even though we only made up $5 \%$ of the population. And only a smidgen of that $5 \%$ actually got any of it' ('Peakoil.com 2011b'). Distrust of the government extends to U.S. foreign policy, which most peakists consider to be motivated not by noble intentions but short-sighted 'energy imperialism'.

The number who connected peak oil to American imperialism in my surveys was telling. A few representative commenters considered oil depletion to be part of 'the impending fall of the U.S. empire' or the 'decline of the West in general, end of American empire', caused by 'Western Civilization's hubristic blindness and imperialistic self-destructive tendency', which would lead to 'the end of the U.S. imperialism'. Even more (more than $10 \%$ of respondents to one survey) cited the imminent peak-oil collapse as the death knell of capitalism. A New York man in his fifties noted that 'capitalism requires constant * growth* [sic] for it to remain viable as an economic system, but that continuous growth may well no longer be possible due to peak oil'. A peakist in her early forties commented that 'capitalism as we know it has grown on the back of cheap energy, particularly oil'.

It would be an overstatement to paint all peakists as conscious anti-imperialists or anti-capitalists, but the close connection that most draw between 
imperialism, capitalism, and petroleum shows that they view the consequences of peak oil as America's proverbial chickens coming home to roost. One article by a reformed peakist claimed, with mild exaggeration, that 'loathing for the United States is a virtual prerequisite for becoming a peak oil acolyte' (Bendzela 2011), and the Virginia man who claimed that 'our American way of life is coming to an end' was not particularly disappointed by this prediction. Like many, he seemed to view the 'end of the oil age' as the end of the American empire and capitalism itself: a crisis, of course, but also an opportunity. Cultural theorist Imre Szeman noted this possibility when he asked, 'Is the end of oil a disaster? This depends, of course, on the perspective one has on the system in danger of collapse: capitalism' (Szeman 2007, p. 808).

While beliefs about inevitable futures have often inspired action, as in the case of Marxism, they can also lead to political quiescence. Instead of becoming more engaged in radical or environmental politics, American peakists became less politically active. Although they followed national and environmental news more closely after becoming 'peak-oil aware', they became less likely to vote or attend marches, rallies, or protests. ${ }^{13}$ What is most striking about this group of leftists is their tendency to see even radical politics as unable to solve environmental problems. While energy concerns have led to a number of recent political campaigns, such as the anti-nuclear movement, peakists have almost totally ignored electoral politics as an avenue to address these issues. One representative respondent described himself as 'cynical and disassociated. Our government is unresponsive, in denial, and ineffectual', while a Colorado man claimed that 'politics is a supreme waste of time'. Like many adherents, Oily Cassandra, a pseudonymous writer and filmmaker who posted a popular peak-oil YouTube video in 2007 (with more than 300,000 views), had previously been active in leftist politics, such as protesting the U.S. invasion of Iraq in 2003. But in 2007, she reported that there was no place for her concerns in mainstream American politics. ${ }^{14}$ Instead of trying to engage in environmental politics around energy depletion and climate change, she told her viewers that 'all you can do is slow down collapse to try and give all of us enough time to figure out how to best release ourselves from the age of oil to a simpler, more intimate way of life' (Cassandra).

\section{From politics to prophecy}

This resignation is motivated by a sense of political alienation and a bleak evaluation of contemporary environmental politics. Peakists are even more sceptical than average Americans of elected politicians - only 3\% said that most members of Congress deserve re-election, compared to $21 \%$ of Americans (Saad 2010a). ${ }^{15}$ This scepticism is reflective, in many ways, of the 'sense of alienation' that a recent CBS poll found 'had ticked up in recent years ... most Americans feel alienated from their political leaders and dissatisfied or angry with Washington' (Montopoli). When historian Timothy P. Weber (1979) pointed out that 'advocates 
of apocalypticism' have typically been 'outsiders, alienated and disinherited from the privileged and powerful' who 'looked for their future redemption from beyond the clouds precisely because they had no recourse in the present' (p. x), he was discussing how marginalised groups embrace extreme religious ideas, but we might very well apply his insight to our secular subject. A core aspect of American political culture in the twenty-first century is a general feeling of political 'alienation' - in one 2011 poll, $73 \%$ of respondents agreed with the claim that 'the people running the country don't really care what happens to you' and $66 \%$ agreed that 'what you think doesn't count very much anymore' (Corso 2011). In a different poll, Americans placed more faith in telemarketers than Congress ('Poll')! This sense of alienation has long been reflected in low voter turnout compared to other industrialised democracies. $^{16}$

This belief in the futility of politics is especially strong for peak-oil believers, who recognise the need for radical changes in environmental policy, but their about-face was also motivated by a relatively sober calculation of the limitations of contemporary American environmental politics. As the United States underwent such a sharp turn to the right over the last three decades (Schulman and Zelizer 2008, Wilentz 2008) that the use of the label 'liberal' can be a political kiss of death and 'socialist' is an insult, leftists - progressives, socialists, anarchists, anti-capitalists, and others - have been politically marginalised. Even with the emergence of the Occupy movement in 2011 (and the re-election of a Democratic president), most leftist political goals remain beyond the pale of mainstream American political culture. This is especially true of environmental initiatives. Although they may be overestimating the consequences of petroleum depletion, ${ }^{17}$ peakists' sense of an imminent ecological crisis is certainly justified one could point, for example, to the grave threats posed by climate change, topsoil erosion, ocean acidification, deforestation, and environmental toxification. Their evaluation of the state of American environmental politics, while perhaps overly defeatist, is not out of touch with the candid assessments of many respected scientists and environmentalists. Indeed, Sarah Amsler (2010) noted, 'there are two prominent narratives of crisis in contemporary environmental politics. One is rooted in fears of ecological catastrophe, and the other in a sort of anthropological pessimism that human beings lack the will or capacity to prevent it' (p. 129).

Since fossil fuels are finite, and the United States is unlikely to transition rapidly away from a petroleum economy, the thinking goes, might oil depletion not deliver a solution to (or salvation from) climate change and ecological crisis? If this seems to be merely wishful or magical thinking, we might ask ourselves which scenario seems more probable: that American politicians, along with leaders from other populous and high-energy consuming countries, collectively decide to reduce their energy usage drastically and convince or require oil companies and petro-states to forego burning every barrel of petroleum, at great economic loss, or that they are forced to do so only when they finally run out of cheap oil? While this line of argumentation is many things - 
pessimistic, defeatist, disheartening - it is neither uninformed nor unrealistic. In fact, it bears some similarities to claims made by advocates of climate mitigation and geoengineering (e.g. Kintisch 2010).

\section{Peak-oil prophecies}

Peakists' passivity can be explained by their sense of political alienation and belief in the futility of action, but it is also enabled by a popular prophecy of the post-oil world. Believers spend a great deal of time on speculation and prediction about the future - the 'Planning for the Future' section of one website alone contains nearly 3000 separate threads, some of which have been viewed more than 300,000 times. ${ }^{18}$ As the peak-oil movement grew in popularity in the mid2000 s - as oil moved to the forefront of American consciousness as a result of the Iraq war, sharp increases in the price of oil and gasoline, and growing evidence of anthropogenic climate change - a number of adherents wrote speculative novels about the post-peak future which have proven particularly influential within the subculture. In them, intransigent contemporary issues are resolved by the fallout of a peak-oil crisis. Thus, their romantic vision of an honest, environmentally balanced future becomes a key aspect of their belief system and political quiescence. Just as scholars have recognised that the apocalyptic doctrines of some evangelical Christians play a crucial role in American politics (Weber 2005), leftist ecological fatalism should be of concern to scholars of environmental politics.

As a window into the transformation of political concerns into prophecy, the genre of peak-oil fiction is instructive. More than a dozen peak-oil novels have been published in English. They are written by dedicated believers, marketed as 'peak-oil novels' and recognised as such on peak-oil forums (e.g. Kaminski 2008). Although a few scholars have discussed these works (Hitchcock 2010, Curtis 2012, LeMenager 2012, Manjikian 2012), they have been treated primarily as works of fiction. As novels, they are curiosities; as works of prophecy, which hundreds of thousands of Americans subscribe to, they take on a greater significance.

In peak-oil fiction, narrative takes a backseat to ideology. The narrator often breaks from the narrative to educate (or propagandise) the reader about the process by which oil depletion and energy scarcity caused the disruption of the status quo, a scramble for survival, and ultimately the collapse of civilisation. They are best categorised by where they locate themselves on this fixed timeline. A few, such as Prelude (Cobb 2010), portray the period just before the expected oil crash, and document the transformative process of becoming 'peak-oil aware'. Novels such as Last Light (Scarrow 2007), Boil Over: The Day the Oil Ran Out (Booth 2010), and Shut Down: A Story of Economic Collapse and Hope (Flynn 2011) focus on an ensemble of diverse characters as they respond to the unexpected collapse of the world around them. 
Each peakist novel contains at least one character who predicted the peak-oil crisis and is now in a better position to survive. This prophet serves as a model for the reader, who can now imagine him/herself as more prepared for these events, constructing a connection between prophecy and fulfilment that often results in a desire for collapse. As participants become more identified with the peak-oil theory - discussing it with friends, family, and co-workers, communicating with other believers on Internet forums, and immersing themselves in peakist books and films - many begin to (perhaps unconsciously) long for the peak-oil collapse to occur. At least one believer noticed this tendency, posting that 'most of the ardent followers seem to really hope it will happen, either 'cause they despise the political/economic status quo or they've put so much time and energy into the issue that they feel the need to be proven right' ('How many people here are rooting for peak oil'). If oil depletion causes the apocalyptic collapse these Jeremiahs predict, they are prophets and potential saviours; if it does not, they are merely paranoid cranks.

James Howard Kunstler's (2008) novel World Made By Hand, which was read by $78 \%$ of respondents to one survey, provides the clearest illustration of the post-apocalyptic redemption of peakism. Readers found the book to be not only 'seriously addictive' but prophetic - many used the words 'real' or 'realistic' to describe the novel. A peakist from Pennsylvania, for example, said, 'I think that World Made by Hand gives quite a probable glimpse of what the post-peak-oil world could be like later this century'. The novel is set in the mid-2020s, a decade and a half after the 'long emergency' (Kunstler 2005) caused by peak oil: gas shortages that led to resource wars, starvation, social collapse, and lethal epidemics. Its primary location is Union Grove, a small town in Upstate New York whose quaint downtown is now inhabited by a few score of aging townspeople who live simple lives without the luxuries of gas and electricity. ${ }^{19}$ Its protagonist and narrator is Robert Earle, a middle-aged white liberal male, the 'former CEO of a technology company' (p. 220) and peak-oil prophet who now works as a carpenter. Without petroleum for transportation or electricity for the Internet, survivors experience the paralysis of geographical isolation. Information about the U.S. government is conveyed through intermittent radio reports, and when Earle mentions at the end of the novel that 'the electricity stayed off, without even a few more additional spasms' (p. 316), we are left to assume that the United States has completely collapsed.

Although most reviewers described World Made By Hand as a dystopia, its post-peak world is actually superior in many ways. A trip to Albany brings into relief the benefits of Union Grove, which has not suffered from war, nuclear attacks, or political corruption. It is a genuine community, founded on mutual aid. The crash of the oil economy has finally caused the fall of capitalism itself, and residents employ a primitive barter economy, simple but fair. Alcoholism and drug addiction are nowhere to be found. The government's absence has forced most survivors to embrace a Jeffersonian self-reliance, and they have gained the dignity of working freely for themselves. By necessity, they have become renaissance 
people, producing not only their own food and housing but their own entertainment, alcohol, and drugs. The survivors, as one character puts it, 'eat real food instead of processed crap full of chemicals. We're not jacked up on coffee and television and sexy advertising all the time. No more anxiety about credit card bills' (p. 38). To emphasise that post-apocalyptic cuisine is actually superior to our own - no fast food, no chemicals, no trans-fatty acids - the narrator lingers on every culinary description. As one reviewer put it, 'you can practically taste the corn bread and the fish that choke this world's now-unpolluted rivers and streams, another upside to that whole end-of-civilization thing' (Salam 2008, p. 15).

Kunstler's agrarian romanticism is mirrored by his readers. In one survey, one out of three peakists admitted to feeling some 'excitement' about the post-peak future. An independent poll found that $37 \%$ were more 'excited' than 'worried' about the 'post-peak years', and 50\% saw the peak-oil collapse as an 'opportunity', not a 'problem' (Howard 2009, p. 4). ${ }^{20}$ Many also believe that the post-peak world will be more environmentally balanced. Decades or centuries after the factories, oil drills, and automobiles have ceased their energies, the planet will recover and survivors will enjoy its rebirth. Less is generally said, in peak-oil fiction and online discussions, of the billions that will perish as a result of ecological crises. In World Made By Hand, post-apocalyptic survivors enjoy a renewed sensitivity to and connection with the natural world. One character notes with pride that 'we follow the natural cycles' (p. 37), and Earle sings the praises of the quiet life: 'I enjoyed the peacefulness and easy pace of the walk. In a car, I remembered, you generally noticed only what was in your head or on the radio, while the landscape seemed dead' (p. 5). Kunstler deploys the pastoral ideal throughout the novel in his lyrical descriptions of the natural world. Note, for example, Earle's description of one of his lovers gutting a fish:

\begin{abstract}
She reached in and removed its guts and flung the guts out in the current. Then she ran her thumb down along the spine inside of the rib cavity to get out the congealed blood there .... Finally, she slipped the fish inside the creel and washed the spine and blood off her fingers in the current. I clapped my hands in appreciation. Hearing that, she finally turned around. What a sight she was in a wet cotton drafts. I kicked off my boots and waded out in the water, scooped her into my arms and carried her back to the gravel bank. (p. 309)
\end{abstract}

The collapse of industrial civilisation provides the narrator with the opportunity to adopt a classically masculine pose. ${ }^{21} \mathrm{~A}$ return to a pioneer lifestyle thus provides a welcome change for the former CEO - and might for you too, it is implied, if you only read the signs and 'prep' for what is to come. In this popular peakist vision of the future, ecological collapse provides a means of both environmental and social regeneration. 


\section{Conclusion}

Although most Americans report being concerned about the environment, their support for green initiatives remains tepid. According to a 2011 poll on Americans' policy priorities, for example, 'global warming' was the second lowest of the 20 options presented (just behind 'lobbyists'), while the general category 'environment' was only slightly ahead, at number 16 ('Pew Research Center for People \& The Press 2011'). In this period of recession, austerity, and continued denial of science (Oreskes and Conway 2011), a broad-based movement for a proportionate, concerted response to the very real ecological crises that the Earth faces does not seem likely in the very near future. We might expect political pressure for serious action to be applied from the minority for whom environmental concerns are a true priority.

For those who hope that the United States will take a more active role in addressing these issues, the level of fatalism expressed by peak-oil believers is troubling. We might expect peak-oil believers, as a group of educated, middleclass leftists who have based their very identities on the threat of environmental destruction and resource depletion, to be at the forefront of demands for changes in environmental policy. Instead, they have become more fatalistic, less politically active, and more quiescent. They note, with a touch of black humour, that peak oil will provide a solution to anthropogenic climate change: the United States will finally be forced to curb emissions when it runs out of inexpensive oil. In some ways, this is a self-fulfilling prophecy: if the most environmentally aware and concerned citizens retreat from the public sphere into individual 'prepping', or even into collective groups such as Transition Towns, the pressure for political action will only diminish.

I have attempted to explain the peak-oil movement's surprising quiescence with reference to their pessimistic appraisal of American environmental politics. Most peakists believe that the United States is simply unable to solve the major problems that the country and planet face, which they identify as peak oil, climate change, and capitalism's demand for infinite growth in a finite world. This belief was summarised by a Nebraska man in his thirties, who believed that political action on these fronts was futile, since the 'social, political, and media systems required to make meaningful headway are dysfunctional. Appropriate responses require a level of discussion that is beyond the capacities of the present system' in the United States.

While we might easily dismiss the impact of the peak-oil movement itself due to its relatively small numbers, we should inspect the relationship between this ecological pessimism and American environmental politics more broadly. We should ask, for example, whether a sense of political alienation and futility have led other environmentally aware Americans to retreat from politics in a similar way. Scholars studying climate psychology (e.g. Nickerson 2003, Whitmarsh and O'Neill 2011) and the role of emotion in environmental communications (e.g. Sangolt and Roald 2012; Roeser 2012) are already engaged in 
these questions, and the example of the American peak-oil movement should be part of this conversation. Of course, the story of peak-oil believers is not yet concluded - although the question of oil scarcity receives less media attention than it did from 2005 to 2008 (Denning 2012) and fewer newcomers are flocking to peak-oil websites - many believers might still be engaged politically. Whether the peak-oil movement is ultimately a cautionary tale of defeatism and quiescence or a narrative of political transformation remains to be seen.

\section{Acknowledgements}

I thank Elaine Tyler May, Kevin P. Murphy, Daniel J. Philippon, Lary May, Cameron Leader-Picone, the editor, and two anonymous reviewers for their assistance.

\section{Notes}

1. This figure emerges from analysis of website membership and posting patterns. See p. 5 for more information.

2. I define 'ideology' as Eric Foner (1970) defined it: as 'the system of beliefs, values, fears, prejudices, reflexes and commitments - in sum, the social consciousness - of a social group, be it a class, a party, or a section' (p. 4). Peakism is marked by many of the standard characteristics of recognised ideologies, including internal coherence; intellectual abstractness, specificity, and sophistication; dogmatism; and affective investment (Shils 1967, pp. 974-978).

3. All unattributed quotations are direct quotations from the author's two surveys of peak-oil believers.

4. Both anonymous surveys used snowball sampling (or 'chain-sampling'), which is particularly effective for recruiting 'hidden' populations. The first survey, conducted in January 2011, gathered 1128 responses from two links on popular peak-oil websites. The second, conducted in July 2011, recruited 628 participants. I allowed any interested party to complete the surveys, and asked respondents to forward the links to their 'peak-oil aware' friends and acquaintances. Specific questions ensured that respondents belonged to the target population. In response to the question, 'If you had to quantify your level of certainty in the fundamental theory of peak oil that global oil production will peak in the next decade (if it hasn't already), and that this event will have grave and potentially apocalyptic effects on the United States and around the world - on a scale of 1 to 10 , what would it be? 1 is disbelief, 10 is complete certainty', $93.8 \%$ of respondents to the first survey and $85.6 \%$ of respondents to the second survey answered ' 7 ' or more. The mean for each question was 8.70 and 8.85 respectively. The potential biases inherent in this methodology - such as the accuracy of self-reported information and self-selection bias - were counterbalanced by other research methods. For example, the potential that the population of peakists who would answer an online survey (or even use a computer) might answer in systematically different ways than peakists who would not answer an online survey (or use a computer) was discounted by interviews with believers at peak-oil conferences and Transition Towns.

5. According to a 2010 census, the average American earned between $\$ 45,000$ and $\$ 74,999$. A total of $80 \%$ of respondents had a college degree, and $36 \%$ had earned an advanced degree. In response to questions about psychological and social factors, respondents seemed remarkably average, although control responses from nonpeakists were not available. Most adherents had little previous experience with 
politics, activism, or extreme beliefs of any kind, and did not report having previously suffered from mental illness.

6. In response to the question, 'Which of the following do you see as most likely for the country you currently reside in? Please rate each on a scale of 0 to 10', American respondents rated the option 'Apocalyptic scenario (i.e. violence, epidemics, dieoff)' with an average of 6.4, while respondents from Canada and Western Europe averaged 5.6. The standard deviation was 2.4.

7. Statistics available at StatCounter.com link on http://www.kunstler.com. Accessed on 1 July 2012.

8. At this time, there were more than 30,000 total members. A March 2009 poll taken by 446 members showed that approximately $63 \%$ of the site's users were American ('Where are peakoil.com visitors from?'). Another Peak Oil News poll showed that relatively few of the site's visitors were 'unique' visitors. While $15 \%$ of the poll's 1406 respondents had only been 'visiting peak oil.com for' one day, 57\% had been visiting the site for at least two years ('I have been visiting').

9. In response to the question, 'As a result of your knowledge of peak oil, have you done any of the following?', $72 \%$ had 'prepared food or other supplies for yourself and your family', $82 \%$ had 'reduced energy usage at your current home', $38 \%$ had 'purchased a more fuel-efficient car', $24 \%$ had 'moved to a smaller or more energyefficient home', and 3\% had 'moved to a Transition Town'.

10. For the sake of brevity, I provide one example of each. Website: The Oil Drum. Blog: Kunstler 2012. Podcast: The Survival Podcast. YouTube Channel: Jocic. Poetry: The Peak Oil Poet. Comic: Davila. Forum: Peak Oil News \& Message Boards. Peak-oil therapy: McMahon.

11. Since 1989, Gallup has asked a similar question: 'How much do you personally worry about global warming?' The results have ranged from only $50 \%$ (in 1998) to $72 \%$ (in 2000); at the time of Howard's poll (2009), $60 \%$ worried 'a great deal' or 'a fair amount' (Newport 2012).

12. In a Washington Post-ABC poll taken two months before this survey, $53 \%$ of Americans agreed that same-sex marriage should be legal, with $44 \%$ against (Somashekhar). The polling statement 'we don't give everyone an equal chance in this country' has been used by researchers to measure sensitivity to (and resentment of) minority groups. In a 2010 survey, the University of Washington Institute for the Study of Ethnicity, Race and Sexuality found that only 55\% of white Americans agreed with this statement (Parker).

13. In response to the question, 'Have you been more or less engaged in the following activities since learning about peak oil? Please put on a scale from 1 to 5 , with 1 for much less engaged, 3 for no change, and 5 for much less engaged', American peakists averaged 2.79 for the option 'attending rallies, marches or protests'.

14. 'Oily Cassandra', personal communication, 1 February 2010.

15. Some survey questions mirrored, word for word, national polls conducted regularly over the last 30 years.

16. Over the last 40 years, voter turnout in the United States has hovered between $36 \%$ and $57 \%$, with non-presidential elections generally in the 30 s and 40 s. This is far below other industrialised countries. For 'lower house' elections, the U.S. average for the 18 elections before 2001 was $48 \%$ turnout of eligible voters. Compare this rate of participation over the same period to Germany $(86 \%)$, Holland $(83 \%)$, Israel (80\%), France (76\%), the United Kingdom (76\%), Canada (74\%), and Spain (73\%). See Franklin 2001.

17. Since there is a finite amount of petroleum on the planet, peak oil is a geologic fact the question is when it will occur and what the consequences will be. Given the number of variables involved, there is no way to predict accurately the event of the 
global peak. The exact number of 'proven reserves' of petroleum is unknown, since oil-producing countries (such as Saudi Arabia) closely guard this information, and many governments tend to overestimate oil reserves to avoid creating a panic. Future technological developments that will allow producers to squeeze more petroleum out of each field are also impossible to predict, as is the public's tolerance for the environmental impact of newer methods of production or 'unconventional' sources (such as tar sands and oil shale).

18. As of 3 March 3 2012, the 'Planning for the Future' thread of Peak Oil News contained 2695 topics. The most popular, 'Today I made/bought/learnt... (for a postoil world)', contained 1936 posts and had been viewed 305,880 times.

19. Although most electricity is not produced from petroleum, Kunstler predicts that peak oil will cause a global social collapse, 'resource wars', and acts of terrorism, which will disrupt the flow of electricity (see p. 15).

20. James L. Howard (and PowerSwitch Energy Awareness) conducted an online survey of nearly 300 peakists in 2009 . While this population could be slightly different from population of the author's surveys, Howard's survey's demographics (on age, gender, country of origin, and a number of other factors) indicate it is a close match.

21. As in conservative survivalist fantasies, Kunstler's prophetic novel embraces regressive gender roles in a reimagination of white masculinity. This aspect of the peak-oil prophecy has been criticised by some female participants as a gendered fantasy of this largely male group.

\section{References}

Amsler, S., 2010. Bringing hope 'to crisis': crisis thinking, ethical action and social change. In: S. Skrimshire, ed. Future ethics: climate change and apocalyptic imagination. London: Continuum, 129-152.

Bailey, I., Hopkins, R., and Wilson, G., 2010. Some things old, some things new: the spatial representations and politics of change of the peak oil relocalisation movement. Geoforum, 41 (4), 595-605.

Bardia, U., 2009. Peak oil: the four stages of a new idea. Energy, 34 (3), 323-326.

Becken, S., 2008. Developing indicators for managing tourism in the face of peak oil. Tourism Management, 29, 695-705.

Bendzela, M., 2011. The end of the end: how the peak oil movement failed [online]. Available from: http://www.opednews.com/articles/The-End-of-The-End-How-t-byMike-Bendzela-110102-802.html [Accessed 10 May 2012].

Booth, J., 2010. Boil over: the day the oil ran out. Seattle, WA: CreateSpace.

Bryner, G., 2008. Failure and opportunity: environmental groups in US climate change policy. Environmental Politics, 17 (2), 319-336.

Cassandra, O., 2007 [online]. Available from: http://www.youtube.com/watch? $\mathrm{v}=\mathrm{vAPf9V3}$ li0 [Accessed 7 September 2012].

Cobb, K., 2010. Prelude. Pittsburgh, PA: Public Interest Communications.

Corso, R., 2011. Harris Poll \#97, 13 September. New York: Harris Poll.

Curtis, F., 2009. Peak globalization: climate change, oil depletion and global trade. Ecological Economics, 69 (2), 427-434.

Curtis, C.P., 2012. Postapocalyptic fiction and the social contract. Lanham, MD: Rowman \& Littlefield.

Davila, C., 2007. Spoiled, 2007, self-published.

Denning, L., 2012. Has peak oil peaked? The Wall Street Journal [online], 26 June. Available from: http://online.wsj.com/article/SB10001424052702304458604577490823345598 042.html [Accessed 8 November 2012]. 
Flynn, W., 2011. Shut down: a story of economic collapse and hope. Seattle, WA: CreateSpace.

Foner, E., 1970. Free soil, free labor, free men: the ideology of the Republican Party before the Civil War. New York: Oxford University Press.

Franklin, M., 2001. Electoral participation. In: R.G. Niemi and H.F. Weisberg, eds. Controversies in voting behavior. Washington, DC: CQ Press, 83-99.

Gonzalez, G.A., 2007. The future of the planet: technology, climate change, and oil depletion. Environmental Politics, 16 (1), 142-146.

Hanlon, P. and McCartney, G., 2008. Peak oil: will it be public health's greatest challenge? Public Health, 122 (7), 647-652.

Heinberg, R., 2003. The party's over: oil, war and the fate of industrial societies. Gabriola Island, BC: New Society.

Heinberg, R., 2007. Peak everything: waking up to a century of decline. Gabriola Island, BC: New Society.

Hitchcock, P., 2010. Oil in an American imaginary. New Formations, 69 (Summer 2010), 81-97.

'How many people here are rooting for peak oil,' 2012 [online]. Available from: http://peakoil.com/forums/how-many-people-here-are-rooting-for-peak-oil-t20704. html [Accessed 5 September 2012].

Howard, J.L., 2009. Global Peak Oil Survey 2009 - initial findings [online]. Available from: http://www.powerswitch.org.uk/portal/images/stories/global_peak_oil_survey/ global_peak_oil_survey_2009_results.pdf [Accessed 10 May 2012].

Jacques, P.J., Dunlap, R.E., and Freeman, M., 2008. The organization of denial: conservative think thanks and environmental skepticism. Environmental Politics, 17 (3), 349-385.

Jocic, D., 2012. The gasoline gangsters [online]. Available from: http://www.gasolinegangsters.com/ [Accessed 1 May 2012].

Kaminski, F., 2008. The post-oil novel: a celebration! [online] Available from: http:// www.energybulletin.net/node/44031 [Accessed 1 March 2012].

Kintisch, E., 2010. Hack the planet: science's best hope - or worst nightmare - for averting climate catastrophe. Hoboken, NJ: John Wiley.

Klare, M.T., 2001. Resource wars: the new landscape of global conflict. New York: Metropolitan Books.

Kunstler, J.H., 2005. The long emergency: surviving the converging catastrophes of the twenty-first century. New York: Grove/Atlantic.

Kunstler, J.H., 2008. World made by hand: a novel. New York: Atlantic Monthly Press.

Kunstler, J.H., 2012. Clusterfuck Nation [online]. Available from: http://kunstler.com/blog [Accessed 1 May 2012].

LeMenager, S., 2012. The aesthetics of petroleum, after oil!. American Literary History, 24 (1), 59-86.

Manjikian, M., 2012. Apocalypse and post-politics: the romance of the end. Lanham, MD: Rowman \& Littlefield.

McMahon, K., 2011. The feisty life [online]. Available from: http://www.feistylife.com/ [Accessed 1 May 2012].

Montopoli, B., 2011. Alienated nation: Americans complain of government disconnect, CBS News [online]. Available from: http://www.cbsnews.com/8301-503544_16220074813-503544.html?tag=cbsnewsMainColumnArea [Accessed 7 September 2012].

Mulligan, S., 2010. Energy, environment, and security: critical links in a post-peak world. Global Environmental Politics, 10 (4), 79-100.

Mulligan, S., 2011. Energy and human ecology: a critical security approach. Environmental Politics, 20 (5), 633-649. 
Newport, F., 2012. Americans' worries about global warming up slightly. Gallup [online]. Available from: http://www.gallup.com/poll/153653/americans-worries-global-warmingslightly.aspx [Accessed 1 September 2012].

Nickerson, R.S., 2003. Psychology and environmental change. Mahwah, NJ: Lawrence Erlbaum Associates.

Niessen, D., 2010. Economic thought and U.S. climate change policy. Cambridge, MA: MIT Press.

Nonnecke, B. and Preece, J., 2000. Lurker demographics: counting the silent. Conference on Human Factors in Computing Systems. The Hague, Netherlands.

North, P., 2010. Eco-localisation as a progressive response to peak oil and climate change: a sympathetic critique. Geoforum, 41 (4), 585-594.

Oreskes, N. and Conway, E.M., 2011. Merchants of doubt: how a handful of scientists obscured the truth on issues from tobacco smoke to global warming. New York: Bloomsbury Press.

Parker, C., 2010. Attitudes on limits to liberty, equality, and Pres. Obama traits by Tea Party Approval [online]. Available from: http://depts.washington.edu/uwiser/Tea\% 20Party\%20Chart\%20\%5Bpdf\%5D-1.pdf [Accessed 1 September 2012].

Peak Oil News \& Message Boards, 2012 [online]. Available from: http://peakoil.com/ [Accessed 1 May 2012].

Peakoil.com, 2011a. 16 reasons to feel really depressed about the direction that the economy is heading [online]. Available from: http://peakoil.com/business/16-reasons-to-feel-really-depressed-about-the-direction-that-the-economy-is-headed/ [Accessed 1 May 2012].

Peakoil.com, 2011b. Breaking: US AAA credit rating downgraded [online]. Available from: http://peakoil.com/forums/breaking-us-aaa-credit-rating-downgraded-t62368105.html [Accessed 15 March 2012].

Roeser, S., 2012. Risk communication, public engagement, and climate change: a role for emotions. Risk Analysis, 32 (6), 1033-1040.

Saad, L., 2010a. Voters issue strong rebuke of incumbents in Congress. Gallup, 7 April.

Saad, L., 2010b. Conservatives remain the largest ideological group in U.S. Gallup, 12 Jan.

Salam, R., 2008. Heralding the end times. New York Sun, 5 March, Arts \& Letters, p. 15.

Sangolt, L. and Roald, V., 2012. Deliberation, rhetoric, and emotion in the discourse on climate change in the European Parliament. Delft: Eburon.

Scarrow, A., 2007. Last light. London: Orion.

Schellenberger, M. and Nordhaus, T., 2004. The death of environmentalism: global warming politics in a post-environmental world. The Breakthrough Institute [online]. Available from: http://www.thebreakthrough.org [Accessed 5 September 2012].

Schulman, B. and Zelizer, J., 2008. Rightward bound: making American conservative in the 1970s. Cambridge, MA: Harvard University Press.

Scott-Cato, M. and Hillier, J., 2010. How could we study climate-related social innovation? Applying Deleuzean philosophy to Transition Towns. Environmental Politics, 19 (6), 869-887.

Shils, E., 1967. Ideology: the concept and function of ideology. In: P. Edwards, ed. The encyclopedia of philosophy 4. New York: MacMillan.

Smith, A., 2011. The Transition Town network: a review of current evolutions and renaissance. Social Movement Studies, 10 (1), 99-105.

Somashekhar, S., 2011. Poll: slim majority backs gay marriage. The Washington Post, 19 March, p. A2.

Szeman, I., 2007. System failure: oil, futurity, and the anticipation of disaster. South Atlantic Quarterly, 106 (4), 805-823. 
Thomashow, M., 1995. Ecological identity: becoming a reflective environmentalism. Cambridge: MIT Press.

Urstadt, B., 2006. Imagine there's no oil: scenes from a liberal apocalypse. Harper's Magazine, August 2006, 31-40.

Weber, T., 1979. Living in the shadow of the second coming: American Premillennialism, 1875-1982. New York: Oxford University Press.

Weber, T., 2005. On the road to Armageddon: how evangelicals became Israel's best friend. Grand Rapids, MI: Baker Academic.

Whitmarsh, L. and O'Neill, S., 2011. Engaging the public with climate change: behaviour change and communication. London: Earthscan.

Wilentz, S., 2008. The age of Reagan: a history, 1974-2008. New York: Harper.

Wilson, B., 2006. Ethnography, the internet, and youth culture: strategies for examining social resistance and 'online-offline' relationships. Canadian Journal of Education, 29 (1), 307-328.

Pew Research Center for People and the Press, 2011. Economy dominates public's agenda, dims hopes for the future [online]. Available from: http://www.people-press. org/2011/01/20/economy-dominates-publics-agenda-dims-hopes-for-the-future/ [Accessed 5 September 2012].

'I have been visiting,' 2009 [online]. Available from: http://peakoil.com/modules.php? name $=$ Suveys\&op=results\&pollID=196/ [Accessed 31 March 2009].

'Planning for the Future,' 2012 [online]. Available from: http://peakoil.com/forums/planning-for-the-future-f8.html [Accessed 3 March 2012].

'The American Dream?' 2011 [online]. Available from: http://peakoil.com/forums/theamerican-dream-t'61397.html [Accessed on 1 May 2012].

The Oil Drum, 2012 [online]. Available from: http://theoildrum.com/ [Accessed 1 May 2012].

The Peak Oil Poet, 2012 [online]. Available from: http://www.oilcrash.com/articles/ poems.htm [Accessed 1 May 2012].

The Survival Podcast, 2010 [online]. Available from: http://www.thesurvivalpodcast.com/ episode-516-a-new-look-at-peak-oil [Accessed 1 May 2012].

'Where are peakoil.com visitors from,' 2009 [online]. Available from: http://peakoil.com/ modules.php?name=Surveys\&op=results\&pollID=48/ [Accessed 31 March 2009]. 